\title{
Adaption of Talent Management Scale into Turkish: Sinop University Case
}

\author{
Elife Dogan Kilic ${ }^{1}$, Huseyin Serin ${ }^{1}$, Ozge Karakus ${ }^{2}$, Ozkan Ergene $^{3}$, E. Cihat Corbaci ${ }^{2}$, Nayil Kilic ${ }^{4}$ \\ ${ }^{1}$ İstanbul University, Faculty of Education, Turkey \\ ${ }^{2}$ Sinop University, Faculty of Education, Turkey \\ ${ }^{3}$ Sakarya University, Faculty of Education, Turkey \\ ${ }^{4}$ Sinop University, Faculty of Arts and Sciences, Turkey \\ Correspondence: Elife Dogan Kilic, İstanbul University, Faculty of Education, Turkey.
}

Received: May 19, 2016

doi:10.11114/jets.v5i1.1602
Online Published: December 20, 2016

URL: http://dx.doi.org/10.11114/jets.v5i1.1602

\begin{abstract}
As a result of globalization, talented employees have been needed in the workplace anymore. With being hired of talented employees, new understanding of management has appeared and talent management has gained importance due to this new understanding. Talent management is a kind of management understanding according to which employees feel motivated and have desire to move forward by taking the initiative, trust in their knowledge and expertise has increased, they believe that they can control the incidents and the conditions which enable them to fulfill the tasks which are suitable and meaningful for them for the sake of organizational purposes have been composed (Doğan, 2006). Talent management is composed of a five-step process, which these steps are hiring, keeping, improving, performance and strengthening personnel. The purpose of this study is to adapt the scale which was used by Oehley (2007) in the thesis of "The Development and Evaluation of a Partial Talent Management Competency Model" for prospective teachers in Turkey. The adaptation study was conducted with 133 prospective teachers who are continuing their education in the Faculty of Education of Sinop University. In the adaptation study, exploratory factor analysis and confirmatory factor analysis were conducted. The original scale is composed of 44 items. In the first step of the adaptation study, 40 items are included in the Turkish form with regard to expert opinions. As a result of exploratory factor analysis conducted, item 8 was excluded from the scale. The scale has come up with 8 sub-dimensions as it is in the original scale. To test its accuracy, confirmatory factor analysis was conducted for 39 items.
\end{abstract}

Keywords: prospective teachers, talent, talent management, university

\section{Introduction}

Change process which is continuing at the global level has brought rivalry with itself (Tabancalı \& Korumaz, 2014). The fact that we live in an era in which rivalry conditions have been sharpened and change has been occurring quite fast causes to seek for new concepts and solutions at the scientific level. Organizations pay attention to human resources management much to catch up with the global rivalry conditions and make a difference and proceed in accordance with awareness of that revealing employees' talents and strengths and making use of them are key to success. Because of this, it could be said that in recent years, the concept of talent management has been regarded as the most effective solution to fulfill innovation needs of organizations and that this approach is among the important issues that interest both organizations and academicians. According to a study conducted with nearly 4000 participants, the approach of "talent management" will maintain its importance in the future (Çırpan, \& Şen, 2009). Accordingly, talent management has been gaining more importance in terms of success of organizations and has had a strategic priority for organizations (Davies \& Davies, 2011).

It is a fact that societies are also affected by globalization and rivalry process and try to maintain their existences and catch up with the developments and developing societies; and one of the responsibilities of the government is to create human resources to compete with the world within the context of educational activities (Acar, 2003). In terms of this, "talent" is beyond to be a concept which interests only business world; it is a concept which is pointing to future and development level of societies and, related to these, to "education". Within this context, the efficiency of educational organizations which are pioneers of social development is directly proportional with talent management and education of human resources who will compete with the world is related to efficient management of educational organizations 
(Tabancalı \& Korumaz, 2014). Because of this reason, the concept of talent management is important not only for organizations but also for schools which are based on individuals and whose basic resource is talent (Davies \& Davies, 2011). Accordingly, the concept of education is defined as the basic factor for school success when the concepts of efficiency of educational organizations and educational administration are taken into consideration (Davies \& Davies, 2011).

Ulgen \& Mirze (2004) suggest that in the organizations in which investments and physical substructures are similar, what makes difference is the talent human resources have. At this point, when educational organizations are considered in terms of talent, many elements (teachers, students, etc.) which effective and hard to control at the input stage could be turned into successful outputs thanks to a straight and effective talent management approach (Baykul, 1992; Tabancalı \& Korumaz, 2014).

Talent is a concept which includes both success and skills such as leadership, creativity, effective time management and practicality within organizational and administrational contexts (Doğan \& Demirel, 2008). In educational organizations, talent management is considered as leading the talent, which points out a process during which the components (teachers especially) composing the organizations are assigned, developed and kept according to their talents and such a management understanding for school success (Tabancalı \& Korumaz, 2014; Davies\&Davies, 2011).

Based on these definitions, it could be claimed that talent management at schools has two dimensions. Firstly, necessity of selection, assignment and development of school principals emerges, which reveals the fact that the process of talent management starts with. Firstly, the selection of the school administrators principal talent management, training and development stands out. This situation implies the selection and training of school administrators. Secondly, it could be asserted that how the administrators assigned to schools organize, develop and manage talent belonged to work force gathered in the organization is crucial to determine the efficacy of the process.

Globalization and rivalry conditions have caused some changes such as decrease in centralization effect for school management, dominance of accountability management understanding; increase in control pf parents at schools, evaluation of education by taking into consideration students' perceptions (Dempster, Freakley \& Perry, 2001). Rivalry conditions among students, among teachers, among schools and among nations are reflected to school management, which is accepted as a situation which increases importance of school leaders in the new era. Because of this reason, the issue of educating school leaders to demonstrate effective leadership qualities has still been popular and it clarifies importance of school leaders for success evidently (Tabancalı \& Korumaz, 2014).

In the $21^{\text {st }}$ century, the notion of management has evolved into the notion of leadership; being a good leader rather than being a good manager has become dominant. In the report published by Hay Group (2008), a global management counseling company, while the former notion of manager refers to hierarchical structure, giving orders, force, one directional communication, inspection, underestimating the past and controlling the resource; leadership has been emphasized and such a structure which supports horizontal composition of leadership roles, use horizontal and multi directional communication channels, composes a flexible structure, deals with the past and creates a trustworthy environment is aimed in the newer management structure, or in other words, talent management.

Davies \& Davies (2011) analyze and state the features a school principal should have in details in the book of "Talent Management in Education". Firstly, they underline that a school leader should analyze the future appropriately, proceed and make decisions accordingly. They add that this could be possible by determining the priorities and creating resources or utilizing from current resources accordingly and effectively to realize these priorities. Strategies are needed to be able to apply talent management into educational organizations. A strategy is a kind of skill which enables to analyze inside and outside of the organization constantly, define the aims, plan the activities to reach these aims and find resources for the sake of giving a direction to the organization and being advantageous in terms of rivalry (Üzün, 2000). A principal who want be successful in talent management should act as a strategic leader. It is mentioned that it is necessity for strategic leaders to evaluate needs of schools by considering the environment and the country in which the school is, to take into consideration every individual who work or exist at the school and to arrange behaviors accordingly and as a result of these, they could ensure participation of employees. Secondly, a school leader should act with the consciousness that contribution to development of people he works with at the school means contribution to development of the school. The third key factor is connected with personal characteristics of effective leaders. Being able to be such a leader that appreciates his followers' success, is not egoist, motivates people around, builds trustworthy relations with people and manages this with the help of trust in himself or herself is important in terms of talent management (Davies \& Davies, 2011). Because of this reason, accepting each employee as talented and keeping these talents in the organizations, making them devoted to their job, attracting new talents for the organizations is becoming more and more important (Peters, 2006).

A school leader who will be able to manage the school where he or she works effectively by taking all these features 
into consideration need to analyze the organizational strategy and values, define and detect talent, be a pioneer of development of talent, create an organizational culture in which success is gained through development of talent and maintaining this process with continuity of which employees are aware (Davies \& Davies, 2011).

When related literature is reviewed, there are three definitions belonged to different groups. While the first group considers talent deficiency as the core, the second group considers talent as the core and the third group defines Human Resources implementations such as hiring, selection, development and performance evaluation as talent management (Oehley, 2007).

Talent management is an approach which requires collaboration and communication among all-level managers, includes various stages such as workforce planning, hiring the personnel, education and development of the personnel, revising the talents, planning success, performance evaluation, keeping the talents and many organizations encounter with obligatorily nowadays (McCauley \& Wakefield, 2006).

Talent management is defined as being sure of choosing the correct person at correct time and place (Cannon and MGgee 2011). Talent management approach is based on philosophy of utilizing from talented employees fully by offering them appropriate environments and training the most talented ones among them as the strategic leader of the future (Çelik \& Zaim, 2011).

Talent management process could change from one author to another. According to McCauley, \& Wakefield (2006), talent management process includes planning workforce, talent conflict analysis, hiring process, training and development activities, keeping activities, talent summaries and back up plans while Talent Management Process is composed of hiring, keeping, developing, performance and strengthening the personnel stages according to Çelik \& Zaim ( 2011).

Hiring process is one of the primary components during this process in terms of defining the features sought in the personnel to fulfill his or her duty actively and properly based on the information gathered from work requirements, work analysis and work definitions. Although criteria of defining the work requirements change from one company to another, cognitive and physical features work requirements must include, work conditions and responsibility taken to pursue the job are main components (Erdoğdu, 2013). It is realized at four stages, which are collecting applicants, selecting, orientation and placement. Firstly, applications are gathered in a pool. Then, talented and people appropriate for the future of the company are chosen and they are placed after orientation process. Lastly, their performance and potential competences are tried to be increased (Çelik \& Zaim, 2011). In the process of hiring, employees should be given assigned works of good quality and talent management should be revealed by prioritizing employee's value (Forman, 2006).

Keeping process is defined as taking precautions to keep the talent that contributes an organization's success. Rewarding, offering development opportunities and career planning are essential elements of keeping process in organization (Ooi, 2009). Keeping process composes the unit structure of the top management according to degree of importance within the activities (planning, providing personnel and keeping, training, performance management) and determines related sub-units. While stating the inner organizational structure, that how many people are at which educational level and have which qualifications is important in terms of determining the responsibilities each person should take (Erdoğdu, 2013). Keeping process is composed of 4 stages, which are organizational culture, current manager, promotion and fit between person and environment. Organizational culture is a system including norms, behaviors, values, beliefs and habits which direct people within an organization. The manager is the person who enables organizations to reach their aims by utilizing from human resources in the organization effectively. Later, employees are promoted to a position which is higher than their present position in terms of authority, responsibility and salary by developing their skills. An employee's fulfilling requirements of the duty to which he or she will be appointed and being consistent with work environment should be considered. When there is no fit between the employee and work environment, Individual-Environment Fit Model is considered. This model examines the problems occurring when an individual's abilities are different from requirements of the duty (Çelik \& Zaim, 2011). In these days, top management executives have realized that talented employees should be kept and their talents should be utilized from effectively to realize organizational targets.

Which programs should be carried out to improve talents and how supportive organizational culture are formed are handled in development process (Alayoğlu, 2010). Development process is composed of four stages, which are competency notion and evaluation process, training and development opportunities, coaching and mentoring and difficulties. Competency is composed of individual's observable behaviors such as knowledge, skill, experience, behavior and motivation which enables to carry out targeted duty with expected performance results (Çelik \& Zaim, 2011) Hiring an appropriate applicant is more meaningful than trying to train an inappropriate employee in the organization. It should be remembered specifically that not every feature is open to develop. Training an employee 
requires more effort and money than hiring an appropriate applicant. Practices of hiring the appropriate applicants will ease management of talents and increase success of Talent Management system built (Çırpan \& Şen 2009).

The concept of performance is defined as the quantity of product or service produced within a certain time period and is named as "activity", "efficiency", and "output" in the literature (Kalkandelen, 1997). Performance is a concept that determines what is obtained at the end of an aimed and planned activity as qualitative or quantitative (Çelik \& Zaim, 2011). Performance process involves an employee's success at work, his/her attitudes and behaviors, his/her moral conditions and characteristics; and it is a planned process that assesses the contributions to the organization's success (Helvac1, 2002). The process of performance evaluation aims to plan, evaluate and develop employee's performances (Iş11, 2008). The main aim of performance management is to create culture in which individuals and groups take responsibility to improve organizational effectiveness, their skills and contributions (Bolton, 1997). Performance process is composed of four stages, which are specified roles, the concept of performance and evaluation process, feedback, recognition and awarding. Here, specified role addresses to appointment of talented employees to positions which are appropriate for them in accordance with organizational aims and strategies. In this way, role conflict, duties' being fulfilled by other employees, will be avoided. At this point, the performance of the appointee is also important (Çelik \& Zaim, 2011). Within the performance management process, all members of the organization are seen as team members rather than in a hierarchy, responsibilities are based on agreement, expectations and development plans and are evaluated as a component of normal interaction between managers and team members (Armstrong, 1996).

Strengthening the personnel in terms of management has been one of compulsory management techniques to have rivalry advantage in the organization. Strengthening in them management could be defined as the process of cooperation, sharing, training and increasing decision making rights of employees via team work and developing the personnel (Koçel, 2005). Personnel strengthening approach has emerged from the need of personnel who make decisions and determine priorities on the behalf of the organization and have qualifications to apply them within their authority and responsibility area (Dalay, Coşkun, \& Altunışı, 2002). Personnel strengthening is also defined as employees' sharing information related to organizational performance and success and sharing authority of making decisions on nominees to be awarded for their performance and other decisions which may affect organizational management and performance (Bowen \& Lawler, 1992). Personnel strengthening includes the conditions in which employees feel motivated, trust their knowledge and expertise, have desire to carry out by taking initiatives, believe that they can control what is going on and do the thing they find suitable and meaningful in accordance with organizational aims. Personnel strengthening is a means of allowing personnel to make a decision. It is the behavior for revealing their potentials, creativity and energy. Personnel strengthened know importance of their job, affect the job they deal with, tell their ideas independently, are aware of their capabilities and talents and always have desire to develop themselves (Doğan, 2006).

The purpose of this study to conduct the adaptation of the scale directed to determine tendencies related to talent management with prospective teachers into Turkish.

\section{Method}

\subsection{Sample}

This is a descriptive study. It is conducted with 133 prospective teachers who are instructed at the Faculty of Education at Sinop University. In the Spring term of 2013-2014 period, 133 participants from the departments of Primary School Teaching, Preschool Teaching and Social Sciences Teaching volunteered to participate in the study. 31 (\% 23.3) of prospective teachers who participated were males and 102 (\%76.7) of prospective teachers who participated were females.

In the study, 60 (\%45.1) of the participants were from Department of Primary School Teaching, 36(\%27.1) of the participants were from Department of Social Sciences Teaching and 37(27.8) of them were from Department of Preschool Teaching.

\subsection{Measurement}

The purpose of this study is to use the scale used by Oehley (2007) in his thesis, "The Development and Evaluation of a Partial Talent Management Competency Model" by adapting it into Turkish.

44-item scale which was translated from its English original form was compared in terms of "language and meaning" by 3 colleagues who are experts who have competency in both of the languages. Then, two experts are consulted related to consistency of items with the purpose and adequacy of items. Two experts in the area of Turkish language and literature examined the items and made suggestions related to them. Rearrangements were made according to suggestions of experts and items which should be excluded from the scale were excluded. Application form was composed as a 40-item draft. The draft form of Talent Management Scale (Yetenek Yönetimi Ölçeği (YYÖ)) was 
applied to 56 participants who were $3^{\text {rd }}$ graders in Department of Preschool Teaching to get feedback on comprehensibility of items and explanations. Application form was composed as 40-item draft. At the end of the application, prospective teachers were interviewed and there were phrase corrections in the 2 items according to their opinions. The scale which was used to collect data in the study was composed of two sections. In the first sections, demographic information was included while in the second section, 40 items related to general talent were included. The scale was prepared as 5-point Likert type scale from Completely Agree (5) to Completely Disagree (0).

\subsection{Analysis}

Construct validity of Talent Management Scale was analyzed with exploratory factor analysis (EFA) and confirmatory factor analysis (CFA). EFA focuses on finding meaningful variables and factors by taking correlations between variables as the starting point and producing a theoretical framework. On the other hand, CFA is used to examine consistency between data invented empirically or composed based on theory in accordance with expert opinion (Büyüköztürk, 2002; Tabachncik \& Fidell, 2001).

In the adaptation study of the scale, item features were taken into consideration firstly. Item-total correlations which shows whether each item in the scale measures the same thing as the total scale were calculated. This correlation coefficient is seen as discrimination rate among the applicants in terms of the scale and the feature measured. For reliability of the scale, Cronbach Alpha internal fit coefficient was considered.

In the study, to get additional evidence for validity of construct which has one-factor 8-sub-dimension structure defined by EFA, CFA was run with the same data. The purpose of CFA run is to examine to what extend one-factor 8-sub-dimension measurement model shows fit. To evaluate validity of CFA model, Chi-square Goodness of Fit Test $\left(\chi^{2}\right)$, GFI, AGFI, RMR/RMS, RMSEA, CFI, NFI and NNFI was run. When the literature is reviewed, it concluded that if the value $\left(\chi^{2} / s d\right)$ calculated by CFA is lower than 3 (Schermelleh-Engel, Moosbrugger \& Müller, 2003) and FI, AGFI, NFI and NNFI values are higher than 0.90 (Anderson \& Gerbing, 1988; Marsh, Balla \& McDonald, 1988), there is an acceptable data fit. Besides, that RMS and RMSEA values are lower than 0.05 is commented that the model is consistent with the data (Şimşek, 2007; Büyüköztürk \& Altun, 2011; Jöroskog \& Sörbom, 1993; Hu \& Bentler, 1999)

\section{Findings}

\subsection{Factor Structure of Talent Management Scale}

To determine factor structure fit of data, KMO test was run and KMO value was found 0.91 and Bartlett test was found 3071,771. Results of Bartlett test was found significant $(p<.005)$. Because of this reason, it is accepted that factor analysis could be applied to data set. By running EFA, factor structure of YYÖ was revealed. Based on the preliminary results of EFA, one item of which factor load was lower than .30 was excluded and the analysis was repeated with 39 items. Results of factor analysis run showed that the scale has one-factor eight sub-dimensions. EFA results are presented in the Table 1.

As a result of the first factor analysis, item 8 of which factor load was lower than .30 was excluded from the analysis. In the second analysis, 39 items of which factor load was equal to or higher than .30 were analyzed. Factor load of these items were presented in the Table 1. In the second factor analysis run, factor loads change between 0.30-0.77. In the second factor analysis, it was found out that the factor loadings ranged from 0.30 to 0.77 .

As Confirmatory Factor Analysis (CFA) is considered as the evidence of validity of the construct measured, the original eight-factor scale and its consistent model were constructed and CFA was run (via LISREL 8.7 program). In the measurement model, for hidden variables representing factors, factor load for one indicator was equalized to $(\lambda) 1.00$ (i1, i5, i10, i15, i21, i27, i32, i36). 
Table 1. Results of Exploratory Factor Analysis of Talent Management Scale

\begin{tabular}{|c|c|c|c|}
\hline \multirow{6}{*}{$\begin{array}{l}\text { Talent Management } \\
\text { Understanding }\end{array}$} & Item No & Factor Communality Variance & Factor Load Value \\
\hline & Item 1 & ,641 &, 568 \\
\hline & Item 2 & ,578 &, 582 \\
\hline & Item 3 & 698 &, 557 \\
\hline & Item 4 & ,589 & 616 \\
\hline & Item 5 & 628 & 630 \\
\hline \multirow{4}{*}{$\begin{array}{l}\text { Hiring the talented } \\
\text { ones }\end{array}$} & Item 6 & 666 &, 585 \\
\hline & Item 7 & .598 & 432 \\
\hline & Item 9 &, 501 & 602 \\
\hline & Item 10 &, 733 & 757 \\
\hline \multirow{6}{*}{$\begin{array}{l}\text { Determining } \\
\text { Talented Ones }\end{array}$} & Item 11 & ,730 & ,650 \\
\hline & Item 12 & ,589 & 457 \\
\hline & İtem13 & 602 &, 710 \\
\hline & Item14 &, 552 &, 581 \\
\hline & Item 15 & 713 & 302 \\
\hline & Item 16 & 674 & 651 \\
\hline \multirow{6}{*}{$\begin{array}{l}\text { Developing } \\
\text { employees }\end{array}$} & Item 17 & ,747 & , 599 \\
\hline & Item 18 & 648 & ,728 \\
\hline & Item 19 & 768 & 751 \\
\hline & Item 20 & 610 &, 537 \\
\hline & Item 21 & 605 &, 731 \\
\hline & Item 22 & 711 & 411 \\
\hline \multirow{6}{*}{$\begin{array}{l}\text { Building } \\
\text { relations }\end{array}$} & Item 23 & ,707 & 661 \\
\hline & Item24 & 697 &, 722 \\
\hline & Item 25 &, 734 & ,737 \\
\hline & Item 26 & 671 &, 730 \\
\hline & Item 27 & 677 & 751 \\
\hline & Item 28 & 633 & ,751 \\
\hline \multirow[t]{4}{*}{ Authorization } & Item29 & 619 &, 717 \\
\hline & Item30 &, 726 &, 536 \\
\hline & Item 31 & ,739 & ,767 \\
\hline & Item32 & 674 & 685 \\
\hline \multirow{5}{*}{ Awarding } & Item33 & ,715 & 771 \\
\hline & Item34 & 682 &, 741 \\
\hline & Item35 & ,673 & ,635 \\
\hline & Item36 & 610 & ,586 \\
\hline & Item37 & ,703 & ,743 \\
\hline \multirow[t]{3}{*}{ Job-Life Balance } & Item38 & ,556 & 636 \\
\hline & Item39 & 662 & 601 \\
\hline & Item 40 &, 558 &, 536 \\
\hline
\end{tabular}

Results of CFA conducted for 40-item scale indicated that item load of Item 8 which is included in IA sub-dimension was found negative (-0.75). After related item was excluded from the analysis, it was observed that RMSEA value decreased while GFI and AGFI values increased (Table 2).

When the related literature was reviewed, that the value obtained by dividing Chi-square value $\left(\chi^{2}\right)$ into degree of serbestlik $\left(\chi^{2} / \mathrm{sd}\right)$ is lower than 3 means acceptable levels for data-model fit (Schermelleh-Engel, Moosbrugger \& Müller, 2003). After CFA, that GFI value is higher than 0.85 and AGFI value is higher than 0.80 indicate an acceptable data fit (Anderson \& Gerbing, 1988; Marsh, Balla \& McDonald, 1988). Besides, that RMSEA value is lower than 0.06 is taken as an acceptable criterion for model data fit (Hu \& Bentler, 1999).

The values presented in the Table 2 show that after CFA, $\chi^{2} /$ sd value is 2.90 , GFI value is 0.87 , AGFI value is 0.84 and RMSEA value is 0.44 indicates an acceptable model data fit in 39-item form of the scale.

Table 2. Important Values for Model Data fit after Confirmatory Factor Analysis

\begin{tabular}{|c|c|c|c|c|}
\hline Values & $\chi^{2} / s d$ & RMSEA & GFI & AGFI \\
\hline 40-Item & 1.44 & 0.056 & 0.85 & 0.89 \\
\hline 39-Item & 2.90 & 0.044 & 0.87 & 0.84 \\
\hline
\end{tabular}

CFA results show that the scale has 8-sub-dimension structure. Path diagram is given in the Figure 1. 


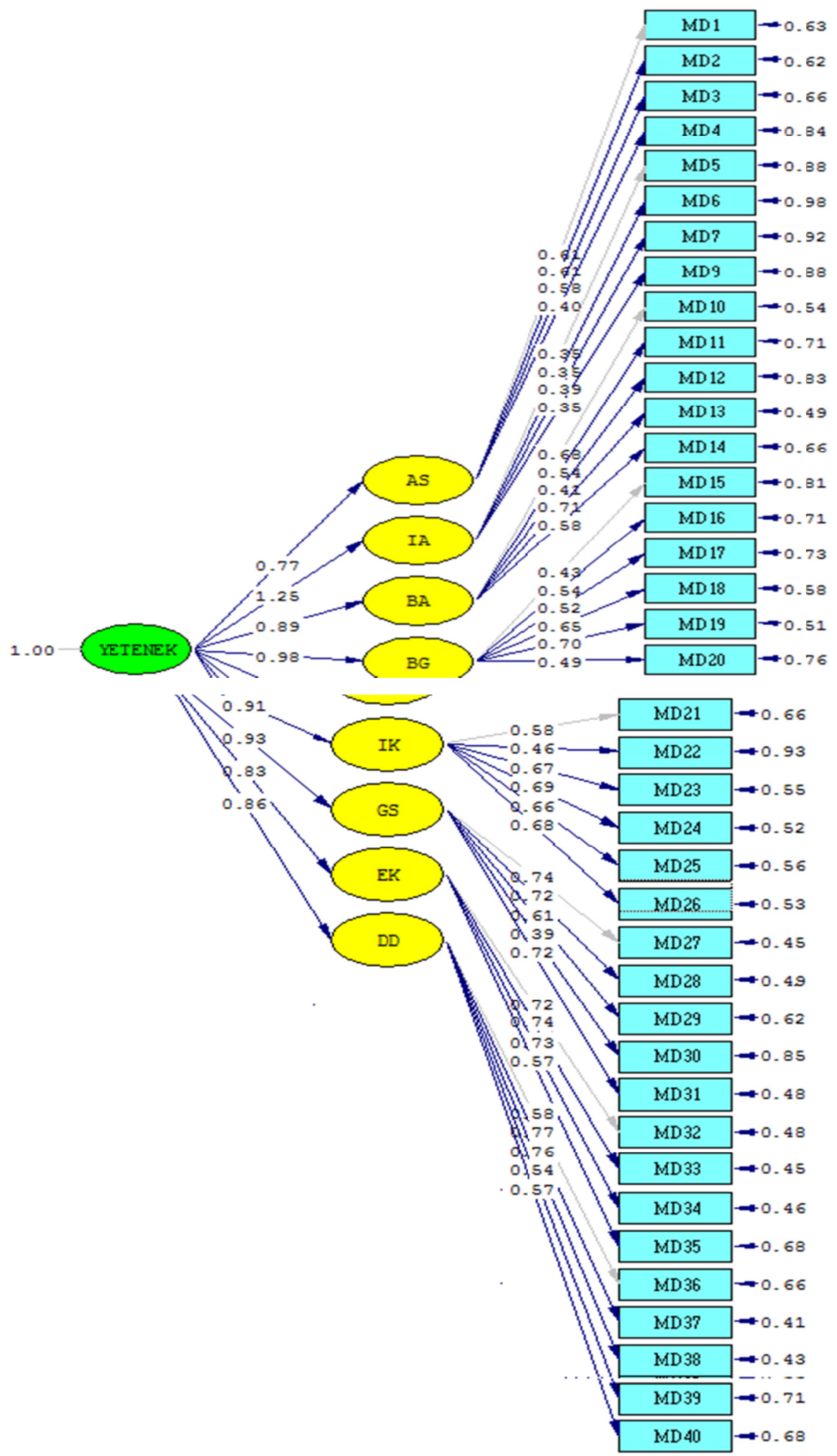

\section{Reliability}

Figure 1. Path diagram

Cronbach alpha internal fit coefficient $\alpha$ was found 0.95 . These results show that items are suitable for factor analysis, construct validity was ensured and it is found reliable. Item 1 of the scale used in the study explains $41.63 \%$, item 2 explains $46.01 \%$, item 3 explains $49.79 \%$, item 4 explains 53.55\%, item 5 explains 57\%, item 6 explains $60 \%$, item 7 $62.98 \%$ and item 8 explains $65.66 \%$. 
Items 1, 2, 3 and 4 compose talent management understanding dimension; items 5, 6, 7 and 9 compose hiring dimension, items 10,11, 12, 13 and 14 compose differentiation of the talented dimension, items 15, 16, 17, 18, 19 and 20 compose development of employees dimension, items $21,22,23,24,25$ and 26 compose building positive relations dimension, items 27, 28, 29, 30 and 31 compose authorization dimension, items 32, 33, 34 and 35 compose awarding dimension and items 36, 37, 38, 39 and 40 compose job-life balance dimension.

\subsection{Discussion and Suggestions}

The purpose of this study is to adapt Talent Management Scale into Turkish. The scale adapted is one-factor 8-dimension. One dimensional structure determined by EFA was examined with CFA later and it was seen that fit statistics calculated met the criterion values defined in the Methodology section. The alpha score (0.95) found was very satisfactory for reliability of the scale.

Having talented employees will cause a different point of view for employees in the educational organizations and other organizations in which talents are desired to be utilized from to realize organizational aims. Starting to evaluate employees who are the most important component of human resources management in educational organizations as talents will contribute success of organizations and create a positive organizational culture. In the process of developing employees, as long as it is allowed for employees to make their own decision, take initiatives and utilize from creating new ideas capability, educational organizations will satisfy the application conditions of talent management with success (Doğan \& Demiral, 2008).

If training programs are applied continuously for applicability of talent management, performance evaluation among employees is conducted based on specific criteria, employees are offered different options to develop their skills and a flexible working environment including continuous learning culture, it will be eased to attract talented employees for educational organizations.

\section{Conclusion}

Structural equation models have widely been used by various disciplines such as ethnology, psychology, sociology, marketing, economy. LISREL is a package program which was developed for structural equation models. Structural equation models can be transformed into regression equations and path diagrams. By using LISREL, a structural equation model can be displayed by a path diagram to show the relationship between variables in the model. Model appropriateness is tested and unknown coefficients in the linear structural equation models are estimated by choosing an appropriate technique.

As a result of the analysis, it is revealed that the scale consists of one factor and eight sub-dimensions as in the original scale. The sub-scales are talent management, hiring the talented ones, determining the talented ones, developing the employees, building positive relations, authorization, awarding, securing job-life balance.

Lewis and Hamilton conclude that research basic of the talent management is poor, it is not different from human resources practices or disciplines and it lives on anecdotes (Lewis and Heckman, 2006: 143). When literature was reviewed, it was revealed that talent management was regarded as the next core component in human resources field and it could have a central role in achieving success in organization by talented employees (Alayoğlu, 2010).

The basic resource of performance development or creating outstanding performance is to have employees with appropriate talents. In order to be successful in ever-changing environment, organizations should enable their employees to reach outstanding performance levels and struggle to maintain it. Competency approach provides organizations to accommodate the change by using present internal resources and strategies effectively (Biçer \& Düztepe, 2003).

An organization that would like to have talented employees and that desires to benefit from employees' new and creative ideas should change its perspective on its employees. The employees who have become the most valuable entities in an organization have been started to be considered as talents to be discovered thanks to understating of talent management concept and the organizations should keep up with this approach. The organizations should also accept that the employee who has the chance to make their own decisions, take initiative and come up with new ideas via personnel strengthening can benefit from their own talent with talent management (Doğan \& Demiral, 2008).

\section{References}

Acar, H. (2003). 21 Yüzyıla Girerken Milli Eğitim Bakanlığında Eğitim Yöneticilerinin Yetiştirilmesi ve Geliştirilmesinde Yeni Yaklaşımlar. Ankara Üniversitesi Eğitim Fakültesi Yayınları

Alayoğlu, N. (2010). İnsan Kaynakları Yönetiminde Yeni Dönem: Yetenek Yönetimi. Ticaret ve Turizm Egitim Fakültesi Dergisi, 68-97.

Anderson, J. C., \& Gerbing, D. W. (1988). Structural Equation Modeling in Practice: A Review and Recommended Two 
Step Approach. Psychological Bulletin, 103(3), 411-423.

Armstrong, M. (1996). Employee Reward. London: Institute of Personnel and Development (IPD) House.

Baykul, Y. (1992). Eğitim Sisteminde Değerlendirme. Hacettepe Üniversitesi Eğitim Fakültesi Dergisi, 7, 85-94.

Biçer, G., \& Düztepe, Ş. (2003). Yetkinlikler ve Yetkinliklerin İşletmeler Açısından Önemi. Havacılık Ve Uzay Teknolojileri Dergisi, 1(2), 13-20.

Bolton, T. (1997). Human Resource Management: An introduction. Massachusetts: Blackwell Publishers.

Bowen, D. E., \& Lawler, E. E. (1992). The Empowerment of Service Workers: What, Why, How and When, Sloan Management Review, 33(3), 31.

Büyüköztürk, Ş. (2002). Faktör Analizi:Temel Kavramlar ve Ölçek geliştirmede

Büyüköztürk, Ş., \& Altun, A. S. (2011). Change Tendencies Scale Development. Kalem İnsan ve Eğitim Bilimleri Dergisi, l(1), 73-90.

Cannon, J. A., \& McGee, R. (2011). Talent Management and Succession Planning 2nd Edition Published by the Chartered Institute of Personnel and Development, London

Çelik, M., \& Zaim, A. H. (2011). Yetenek Yönetimi Yaklaşımı Istanbul Ticaret Üniversitesi Fen Bilimleri Dergisi, 10(20), 33-38.

Çırpan, H., \& Şen, A. (2009). İşletmelerde Yenilikçiliği Geliştirmede Etkili Bir Araç: Yetenek Yönetimi. Çerçeve Dergisi, Eylül Saylsl, 110-116. http://butunselliderlik.com/pdf/yetenek_yonetimi.pdf

Dalay, İ., Coşkun, R., \& Altunışık, R. (2002). Stratejik Boyutuyla Modern Yönetim Yaklaşımları, İstanbul: Beta Basım Yayım Dă̆ı̆ım

Davies, B., \& Davies, B. (2011). Talent Management in Education. Sage Publications: London.

Dempster, N., Freakley, M., \& Parry, L. (2001). The Ethical Climate of Schooling under New Public Management. The International Journal of Leadership in Education, 4(1), 1-12.

Doğan, S. (2006). Personel Güçlendirme, 2. Baskı, Kare Yayınları, Ankara.

Doğan, S., \& Demiral, Ö. (2008). İnsan Kaynakları Yönetiminde Çalı̧̧anların Kendine Doğru Yolculuk Yöntemi: Yetenek Yönetimi. Çukurova Üniversitesi Sosyal Bilimler Enstitüsü Dergisi, 17(3), 145-166.

Erdoğdu, E. (2013). İnsan Kaynakları Yönetiminde Personel Seçimi ve Psikoteknik Testlerin Önemi Atılım Üniversitesi. Sosyal Bilimler Enstitüsü Yayımlanmamış Yüksek lisans Tezi

Forman, C. D. (2006). Talent Metrics. Leadership Excellence, 23(1), 6-7.

Helvac1, M. A. (2002). The Importance of Performance Appraisal in Performance Managament Process. Aaakra University, Journal of Faculty of Educational Science, 35(1-2), 155-169

Hu, L., \& Bentler, P. M. (1999). Cutoff criteria for fit indexes in covariance structure analysis: Conventional criteria versus new alternatives. Structural Equation Modeling, 6, 1-55.

Jöreskog, K. G., \& Sörbom, D. (1993). LISREL 8: Structural Equation Modeling with the Simplis Command Language. Lincolnwood: Scientific SoftwareInternational

Kalkandelen, H. (1997). Örgütlerde Yeniden Yapılanma ve Norm Kadro. Anı Yayınları. Ankara.

Koçel, T. (2005). İşletme Yöneticiliği, Beta Basım Yayım Dă̆ıtım A.Ş., İstanbul Kullanımı. Eğitim Yönetimi Dergisi, 470-483.

Lewis, R. E., \& Heckman, R. J. (2006). Talent management: A critical review. Human Resource Management Review, 16, 139-154.

Marsh, H. W., Balla, J. R., \& McDonald, R. P. (1988). Goodness of fit indexes in confirmatory factor analysis: The effect of sample size. Psychological Bulletin, 103, 391-410.

McCauley, C., \& Wakefield, M. (2006). Talent Management in the 21st Century: Help Your Company Find, Develop And Keep its Strongest Workers", The Journal For Quality \& Participation, Winter, 29(4), 4.

Oehley, A. M. (2007). The Development and Evaluation of A Partial Talent Management Competency Model. Thesis presented in partial fulfilment of the requirements for the degree of Master of Arts at Stellenbosch University.

Ooi, C. S. S. (2009). Surviving the war for talent in Asia: how innovation can help. Indiana-USA: R.R. Donnelley in Crawfordsville. 
Peters, T. (2006). Leaders as Talent Fanatics. Leadership Excellence, 23(11), 12-13.

Schermelleh-Engel, K., Moosbrugger, H., \& Müller, H. (2003). Evaluating the fit of structural equation models: Test of significance and descriptive goodness-of-fit measures. Methods of Psychological Research - Online, 8(2), 23-74.

Şimşek, Ö. F. (2007), Yapısal Eşitlik Modellemesine Giriş, Temel İlkeler ve Lisrel Uygulamaları, Ekinoks Yayınları, Ankara, 212.

Tabachnick , B. G., \& Fidell, L. S. (2001). Using Multivariate Statistics (4th Edition). New York: Allyn \& Bacon.

Tabancalı, E., \& Korumaz, M. (2014). Eğitim Örgütlerinde Yetenek Yönetimi. The Journal of Academic Social Science Studies, 25(I), 139-156.

The Hay Group (2008). Rush to the Top: Accelerating the Development of Leaders in Public Services.

Ülgen, H., \& Mirze, K. (2004). İşletmelerde Stratejik Yönetim. Literatür Yayınevi: İstanbul.

Üzün, C. (2000).Stratejik Yönetim ve Halkla İlişkiler, Eylül Yayınları, İzmir.

\section{$(\mathrm{Cc}) \mathrm{BY}$}

This work is licensed under a Creative Commons Attribution 3.0 License. 